\title{
Fluctuationing Value of Rupee \& Impact on Economy
}

\author{
${ }^{1}$ Nand kishor Soni, Research Scholar, ${ }^{2}$ Ajay Parashar Asst. Professor \\ Department of Economics Barkat Ullah Universaity Bhopal(MP), \\ Department of Economics(Govt.PG College Pipariya(MP)
}

\begin{abstract}
Global economy is much more interlinked than it was earlier due to lot of trade taking place between different countries. It goes without saying that U.S. is major trading partner for many nations and biggest trading importer of goods and services from across the world. Change in any direction in U.S. economy is directly going to affect economy of all related countries. Democratic principle and human capital has given India unique position among world community. Indian economic policies are flexible enough to get adjusted to the other nations. India has always been major country when it comes to being trading partner of U.S. which has always given economic and strategic support to country like India occupying strategic importance among world community.

This paper is conceptual study based on Indian Rupee Fluctuation VS Dollar and relationship in terms of Rupee appreciation that is dollar depreciation and rupee depreciation that is dollar appreciation. It provides valuable insights into impact of changes in currency relations on various sectors of economy keeping in focus economy in general and Indian economy in particular. Pros and Cons of currency appreciation and depreciation are studied as boon and bane for the economic growth.
\end{abstract}

Keywords: Appreciation, Rupee Fluctuation, Depreciation, Rupee-Dollar.

\section{Induction}

The rupee has depreciated by more than 18 percent since May 2011, moreover with The rupee breaching the 53 dollar mark, profit margins of companies that import commodities or components would come under severe pressure, which could result in price increases for the consumer. The rupee depreciation will particularly hit the industrial sector and put higher pressure on their costs as items like oil, imported coal, metals and minerals, imported industrial intermediate products all are getting affected. Although the prices of most of the imported commodities have fallen, the depreciating rupee has meant that the importer gets no respite as they need to pay more to purchase the same quantity of raw materials. The depreciating rupee would keep the price of imported commodities elevated. Thus the industrial sector is bound to get adversely hit the appreciating rupee is posing a unique set of challenges for the Indian economy. The impact would not be limited to macro economy alone but it will also affect down to the level of firms under various sections of economy. This is conceptual study based on Rupee Dollar relationship in terms of Rupee appreciation that is dollar depreciation and rupee depreciation that is dollar appreciation.

\section{OBJECTIVES}

This is conceptual study based on Rupee Dollar relationship in terms of Rupee appreciation that is dollar depreciation and rupee depreciation that is dollar appreciation. It provides valuable insights into impact of changes in currency relations on various sectors of economy keeping in focus economy in general and Indian economy in particular. Pros and Cons of currency appreciation and depreciation are studied as boon and bane for the economic growth. It also provides suggestions or steps needed to control as well as to overcome illeffects of excessive fluctuations between rupee and dollar keeping in view current trends.

\section{Related Literature}

Ever since the advent of the ARCH model by Engle (1982), research on the transmission mechanism of volatility between various segments of the financial market has been fast advancing. The application of $\mathrm{ARCH}$ and its generalized form, i.e., GARCH has advanced rapidly in examining volatility transmission among stock markets. Studies on volatility transmission based on low-frequency foreign exchange data are, however, relatively sparse. The initial application of GARCH model to the foreign exchange market could be traced back to the works of Diebold and Nerlove (1989). They employed a vector autoregressive (VAR) model as a basis for the variance decomposition of forecast error variances in order to measure the magnitude of return and volatility spillovers in the foreign exchange market. Bollerslev (1990) used a model with time-varying conditional variances and co-variances, but constant conditional correlations, to model a set of five nominal European-US Dollar exchange rates in the period before and after the inception of the European Monetary System (EMS). 
Engle, et al. (1990) examined the heat waves and meteor showers hypothesis with the help of GARCH model using in tardily data. Their empirical evidence was generally against the heat wave hypothesis. However, in terms of country-specific news, they found that Tokyo news had the largest impact on the volatility spillovers of the JPY/USD exchange rate.

\section{HISTORY OF INDIAN RUPEE VS US \$}

From 1950 to 1973 Indian rupee was linked to British pound. In 1966 and 1973 devaluation happened. On 24th September 1975, the connection between Indian rupee and pound was broken in 1975; the rupee ties to the pound sterling were disengaged. India established a float exchange regime with the rupee's effective rate placed on a controlled, floating basis and linked to a basket of currencies" of India's major trading partners. In 1993 Liberalized exchange rate system (LERMS) was replaced by the unified exchange rate System and hence the system of market determined exchange rate was adopted. However, the Indian rupee and its exchange rate historically.

TABLE-1

VALUES OF INDIAN RUPEE AGAINST US DOLLAR SINCE 1950-2013

[Approximate. Avg. for the year]

\begin{tabular}{|l|l|l|l|l|l|l|l|l|l|}
\hline \multicolumn{10}{|c|}{ HISTORICAL INDIAN RUPEE RATE (INR) } \\
\hline YEAR & INR/USD & YEAR & INR/USD & YEAR & INR/USD & YEAR & INR/USD & YEAR & INR/USD \\
\hline 1950 & 4.79 & 1963 & 7.55 & 1976 & 8.97 & 1989 & 30.21 & 2002 & 48.62 \\
\hline 1951 & 4.55 & 1964 & 8.02 & 1977 & 8.77 & 1990 & 32.42 & 2003 & 46.6 \\
\hline 1952 & 4.79 & 1965 & 7.77 & 1978 & 8.2 & 1991 & 41.32 & 2004 & 45.28 \\
\hline 1953 & 4.55 & 1966 & 7.8 & 1979 & 8.16 & 1992 & 43.23 & 2005 & 44.1 \\
\hline 1954 & 4.75 & 1967 & 8.56 & 1980 & 7.89 & 1993 & 45.28 & 2006 & 45.17 \\
\hline 1955 & 4.78 & 1968 & 8.3 & 1981 & 8.68 & 1994 & 44.31 & 2007 & 41.2 \\
\hline 1956 & 6.67 & 1969 & 8.1 & 1982 & 9.48 & 1995 & 45.00 & 2008 & 43.41 \\
\hline 1957 & 6.8 & 1970 & 7.86 & 1983 & 10.11 & 1996 & 35.52 & 2009 & 48.32 \\
\hline 1958 & 7.2 & 1971 & 7.52 & 1984 & 11.36 & 1997 & 36.36 & 2010 & 45.65 \\
\hline 1959 & 7.4 & 1972 & 7.21 & 1985 & 12.34 & 1998 & 41.33 & 2011 & 51.23 \\
\hline 1960 & 6.3 & 1973 & 7.66 & 1986 & 12.6 & 1999 & 43.12 & 2012 & 57.78 \\
\hline 1961 & 5.8 & 1974 & 8.03 & 1987 & 12.95 & 2000 & 45.00 & 2013 & 63.76 \\
\hline 1962 & 7.6 & 1975 & 8.41 & 1988 & 13.91 & 2001 & 47.23 & & \\
\hline
\end{tabular}

Sources: - RBI Bulletins \& economic times

Before 2011 India had faced two major devaluations that are in the year 1966 and 1991. So let's understand the reasons and the measures adopted by government for the major devaluations that took place in India. The Indian rupee has dropped by nearly $4 \%$ to a new low of 68.7 to the US dollar amid growing concerns over the health of the country's economy. The decline comes a day after India approved infrastructure projects worth $\$ 28.4 \mathrm{bn}(£ 17.7 \mathrm{bn})$ to try to revive the economy and prop up its currency. The rupee has lost $20 \%$ of its value this year and is one of the world's worst-performing currencies. It has also been hit by fears that the US will scale back stimulus measures. The US central bank has sought to increase liquidity in the US economy, through its policy of quantitative easing, in an attempt to boost growth. A part of that liquidity has flowed into Asian markets, such as India, and lifted stock and asset prices. However, the Federal Reserve has said it will scale back the program if the US economy improves, with some analysts expecting this "tapering" to begin as soon as next month. That has seen investors pull money out of emerging markets, hurting currencies and stocks in those countries. The Indian Rupee has depreciated to an all time low with respect to the US Dollar. On 28th August 2013, the Indian rupee had gone down to 68.825 against the Dollar but the situation was somewhat revived by the Reserve Bank of India that decided to open a special window for helping state owned oil companies - Indian Oil Corp Ltd., Bharat Petroleum Corp and Hindustan Petroleum Corp. The beneficiaries will be able to buy dollars through this window till further notice is provided. These companies, together, require about 8.5 billion dollars every month to import oil and it is expected that this will help them meet the requirements. This has had an immediate effect as is evident from the fact that the INR has started at 67 against the USD at the early proceedings in the Interbank Foreign Exchange Market. The question, however, is why this is happening. There are several reasons and its effects that can be enumerated in such a bellow:

\section{RUPEE AND DOLLAR - AS CURRENCY}

Determining what causes currency to weaken or strengthen is an evolving art and it is more of an art than science. In India, level of foreign exchange reserve being low in the past and demand for foreign 
currencies particularly dollar being heavy, the dollar always used to be at premium. Consequently, rupee used to be weak against dollar in the foreign exchange market which is changing now and rupee is becoming strong.

\section{Impact on Currency}

Inflation rates in India have risen about $8.50 \%$ amid concerns surrounding the devaluation of the rupee and the erosion of the purchasing power of savings. In spite of Governmental interventions, the rupee is in a free-fall, having slipped by over $20 \%$, making it one of the most awful performing currencies globally. RBI made thirteen rate increases attempts to docile the inflation in last one year but hardly achieved any significant result. Inflation rate maintained upwards trend. This is now reflected through the currency depreciation. Inflation directly enhances prices and thereby affects the purchasing power of currency. Currency value and inflation have a direct co- relation and impact each other. The currency re-evaluation is also essential with the change in domestic prices affected by inflationary forces. Currency is considered to be overvalued if the suitable adjustment is not made with the price index fluctuations.

\section{Impact on Gold}

India currency devaluation has also resulted in surge of import by over $200 \%$ of gold and silver. Statistics show that imports of gold and silver to India were $\$ 8.96$ billion a growth of $222 \%$. The Reserve Bank of India purchased 200 tons of gold from the International Monetary Fund in 2009. From the start of 2011, some 30 banks in India have been granted permission to import gold and silver. Further gold purchases are expected in coming months, as the Reserve Bank has issued licenses to seven more banks to import gold and silver. Indian banks are therefore contributing to the massive increase in demand for gold and silver. Chinese banks are also catering to the increased demand of Chinese people for gold bullion for investment and savings purposes. In fact, most of the world's central banks are now diversifying from major currencies such as the dollar and euro into gold. In addition to India and China, these countries include Russia, Sri Lanka, Bangladesh, Mauritius, Mexico, Iran and Saudi Arabia. Financial experts believe the increased demand for gold and silver from India and wider Asia is sustainable and that it will keep the precious metal market thriving.

\section{Impact on Stock Market}

As a result of de- valuation, Indian stock markets will face new threats. The operators and participants were earlier concerned about domestic inflation rate and the Reserve Bank of India's economic policies. But the fall in the value of Indian currency has taken aback all concerned. The investors are bound to suffer as there is always a positive correlation between stock index and corporate results. Impact on Market Forecast The wide-ranging perception in the financial market is that until the global macroeconomic environment settles, the rupee will continue to be under pressure. "India's external position has become increasingly vulnerable to global risk appetite. Further weakness cannot be ruled out," Royal Bank of Scotland said in a research note. The rupee is down $14.80 \%$ on the year, with the closest loser among other Asian units being the Thai baht, which has shed just 3.2\%, followed by the Malaysian ringgit that is down 3\%. The rupee's slither may continue due to the decline in foreign exchange inflows and swelling outflows. The Euro zone, the world's largest trading block and India's biggest trading partner, is also in a deep crisis. In times to come, this zone has to stabilize to bring some semblance of order to the global currency markets. Numbers of Indian scams have also distracted government's concentration away from economy. These scams make the bad image of India in the global market.

\section{Conclusion}

The initial success story of India was clearly based on factor driven economy based on labor arbitrage that is providing low cost labor in comparison to another country. At this stage development is sensitive to global business cycle and exchange rate fluctuation. We need to move towards being investment driven economy that is efficiency driven in the form of infrastructure development, improving skill of work force and make that investment which translate into tangible productivity across the board. Final stage which can make India to be developed economy is to be innovation driven economy that can create unique value of India at global economy level. We need to accelerate reform process that would make economy resistant to external shocks and changes in economy cycles and currency fluctuations. The bottom line is our policy should concentrate on enhancing our capability in manufacturing, promote entrepreneurship and provide incentive for innovations. We need to remember that the challenge which we are facing is not only about currency risk but it is about moving to growth and development.

\section{Acknoledgement}

I would like to gratefully and sincerely thank Dr. M. K. Singhai, his guidance, understanding, patience, and most importantly, his friendship during my preparing research paper and V. Sharma, His 
mentorship was paramount in providing a well rounded experience consistent my long-term career goals. I would also like to thank Dr. P. K. Jain, his assistance and guidance in getting my career started on the right foot and providing me with the foundation for becoming a synthetic data. Although his decision to promote my efficiency. Finally, and most importantly, I would like to thank my friends Arvind Mishra. He support, encouragement, quiet patience and unwavering love were undeniably the bedrock upon which the past ten years of my life have been built. Her tolerance of my occasional vulgar moods is a testament in itself of her unyielding devotion and love. I thank my parents, Shri Maheshwari Deen Soni and Smt. Tulsa for their faith in me and allowing me to be as ambitious as I wanted. It was under their watchful eye that I gained so much drive and an ability to tackle challenges head on.

\section{References}

[1]. Amit Kapoor (2007) "Rising Rupee and India Growth Story", the Economics Times, August 29.

[2]. Bollerslev, T. (1986), "Generalized autoregressive conditional heteroscedasticity", Journal of Econometrics, 31, 309-328.

[3]. C. R. L. Narsimhan (2003) "Rising Rupees Hidden Massage", The Hindu, April 32003.

[4]. Engle, R. F. (1982), "Autoregressive conditional heteroscedasticity with estimates of the variance of UK inflation", Econometrica, 50, 987-1008.

[5]. Engle, R.F., D. Lilien and R. Robins (1987), "Estimating time varying risk premia in the term structure: The ARCH-M model", Econometrica, 55, 391-407.

[6]. Engle, R.F., T. Ito and W.L. Lin (1990), "Meteor showers or heat waves? Heteroskedastic intra-daily volatility in the foreign exchange market", Econometrica, 58 (3), 525-542.

[7]. Gokarn, Subir (2012), “An assessment of recent macroeconomic developments", RBI Bulletin, January 2012

[8]. M.K Venu (2007)“Is the us facing liquidity trap?", The Economics Times, September 4. Jitendra Sahai (1982) "Dollar in India", Published by National Publishers, 1982.

[9]. Gray Shoup (2006)“Foreign Currency Management”, Published by Infinity Groups.

[10]. M.Y.Phansalkar(2005) "All about Foreign Exchange and Foreign Trade", Published by English Edition.

[11]. Melvin, M. and M.P. Taylor (2009), "The crisis in the foreign exchange market",Journal of International Money and Finance, 1317-1330.

[12]. Nagendra Chowdhary "Dynamics of Exchange Management", ICFAI Books

[13]. Pattanaik, Sitikantha and Satyananda Sahoo (2003), "The effectiveness of intervention in India: An empirical assessment", RBI Occasional Papers, June, Vol. 22.

[14]. Reserve Bank of India (RBI) http://www.rbi.org.in/scripts/publications.aspx?publication=Annual

[15]. Shruti Chauhan \& Paramita Chatterjee (2007) "Ship Your Worries", The Economics Times, September 11

[16]. Shankar Acharya (2007) "Exchange Rate Policy", Business Standard, April 26. 